\title{
Paratuberculosis in a dairy Gyr herd in the State of Paraíba, Brazil ${ }^{1}$
}

\author{
Pedro M.P.C. Mota ${ }^{2}$, Prhiscylla S. Pires ${ }^{3}$, Ronnie A. de Assis², Felipe M. \\ Salvarani ${ }^{3}$, Ricardo de M.H. Leite ${ }^{4}$, Liliane D. Dias ${ }^{3}$, Rômulo C. Leite ${ }^{3}$, \\ Francisco C.F. Lobato ${ }^{3}$, Roberto M.C. Guedes ${ }^{3}$ and Andrey P. Lage ${ }^{3^{*}}$
}

\begin{abstract}
Mota P.M.P.C., Pires P.S., Assis R.A. Salvarani F.M., Leite R.M.H., Dias L.D., Leite R.C., Lobato F.C.F., Guedes R.M.C. \& Lage A.P. 2009. Paratuberculosis in a dairy Gyr herd in the State of Paraíba, Brazil. Pesquisa Veterinária Brasileira 29(9):703-706. Laboratório de Bacteriologia Aplicada, Departamento de Medicina Veterinária Preventiva, Escola de Veterinária, Universidade Federal de Minas Gerais, Cx. Postal 567, Belo Horizonte, MG 30123-970, Brazil. E-mail: alage@ vet.ufmg.br

This paper describes the clinical, pathological, and microbiologic aspects of paratuberculosis (Johne's disease) in a dairy Gyr herd in the State of Paraíba, northeastern Brazil. An eight years old cow with chronic unresponsive diarrhea was clinically examined and euthanized for pathological evaluation. Fecal samples from all 160 animals over 12 months of age from the herd were collected for isolation of Mycobacterium avium subsp. paratuberculosis. Clinically, the index case cow was severely dehydrated, cachectic, with profuse mucous diarrhea. The main post-mortem findings were emaciation and thickened intestinal wall. Microscopically, the intestinal lamina propria and submucosa were infiltrated by macrophages, epithelioid cells, and Langhans giant cells with numerous alcohol-acid resistant bacilli in the cytoplasm. Two fecal samples displayed growth in slants of Herrold's egg-yolk agar supplemented with mycobactin J, 150 days after incubation. No growth was noticed in slants without mycobactin J. Microscopic examination of the isolated microorganisms stained by Ziehl-Neelsen revealed considerable amounts of alcohol-acid resistant bacilli, morphologically compatible with Mycobacterium spp. Based on the clinical signs, gross and histological lesions, growth time, bacterial morphology in Ziehl-Neelsen staining, and dependence of mycobactin $\mathrm{J}$, the first diagnosis of paratuberculosis in Zebu cattle was made.
\end{abstract}

INDEX TERMS: Mycobacterium avium subsp. paratuberculosis, paratuberculosis, cattle, Paraíba, Brazil.

RESUMO.- [Paratuberculose em um rebanho Gir leiteiro no Estado da Paraíba Brasil.] Objetivou-se descrever os aspectos clínicos, anátomo-histopatológicos e microbiológicos da paratuberculose em um rebanho Gir

\footnotetext{
${ }^{1}$ Recebido em January 19, 2009.

Accepted for publication on April 1, 2009.

${ }^{2}$ Laboratório Nacional Agropecuário, Ministério da Agricultura, Pecuária e Abastecimento, Av. Rômulo Joviano $\mathrm{s} / \mathrm{h}$, Pedro Leopoldo, MG 33600-000, Brazil.

${ }^{3}$ Núcleo de Pesquisa em Saúde Animal, Departamento de Medicina Veterinária Preventiva, Escola de Veterinária da Universidade Federal de Minas Gerais, Av. Antônio Carlos 6627, Cx. Postal 567, Belo Horizonte, MG 30123-970, Brazil. *Corresponding author: alage@ vet.ufmg.br

${ }^{4}$ Empresa de Pesquisa Agropecuária da Paraíba, Rua Eurípedes Tavares 210, Cx. Postal 275, João Pessoa, PB 58013-290, Brazil.
}

leiteiro no Estado da Paraíba. Uma vaca de oito anos que apresentava diarréia persistente, refratária a tratamento foi necropsiada para estudo anátamo-histopatológico. Também foram coletadas amostras de fezes de todos os 160 animais do plantel, com idade superior a 12 meses, para tentativa de isolamento de Mycobacterium avium subsp. paratuberculosis. Ao exame clínico, o animal caso índice apresentou caquexia, diarréia profusa e desidratação grave. À necropsia, o animal apresentou-se emaciado e, ao exame detalhado do trato digestivo, foi observado espessamento da parede e superfície mucosa do íleo e intestino grosso. À microscopia, verificou-se intensa infiltração de macrófagos espumosos associado a raras células epiteliódes e gigantes do tipo Langerhans na lâmina própria e submucosa. À coloração de Ziehl-Neelsen fo- 
ram observadas miríade de bacilos álcool-ácido resistentes no citoplasma destas células. Houve crescimento de colônias bacterianas em duas das 160 amostras de fezes após 150 dias de incubação em tubos com meio Herrold's egg-yolk suplementados com micobactina $\mathrm{J}$ e ausência de crescimento nos tubos com mesmo meio, mas sem suplementação. Os microrganismos isolados foram corados pelo Ziehl-Neelsen observando-se presença de grande quantidade de bacilos álcool-ácido resistente, com morfologia compatível ao gênero Mycobacterium. Baseado na história clínica, achados anátomo-histopatológicos e histoquímicos (Ziehl-Neelsen), e microbiológicos, firmouse o primeiro diagnóstico de paratuberculose em Zebu na Paraíba.

TERMOS DE INDEXAÇÃO: Mycobacterium avium subsp. paratuberculosis, paratuberculose, bovino, Paraíba, Brasil.

\section{INTRODUCTION}

Paratuberculosis is a chronic granulomatous enteritis affecting both domestic and wild animals. Its etiological agent is Mycobaterium avium subsp. paratuberculosis. Also known as Johne's disease, paratuberculosis results in decreased production, progressive weight loss, higher susceptibility to other diseases, and higher culling rate (Tiwari et al. 2006).

Cattle infected with $M$. avium subsp. paratuberculosis can be framed in one of four clinical stages of the disease, according to the severity, disseminating potential, and easiness of laboratorial detection (Whitlock \& Buergelt 1996). Most infected animals are asymptomatic (McKenna et al. 2006), and laboratorial help is needed to diagnose the disease. The gold standard is isolation of the agent from fecal samples (Tiwari et al. 2006).

Johne's disease in Brazilian cattle was first reported in the State of Rio de Janeiro (Dupont 1915). Afterwards, paratuberculosis was reported in the Southeastern region (Santos \& Silva 1956, Darcoso Filho et al. 1960, Silva \& Pizelli 1961, Nakajima et al. 1991, Fonseca et al. 1999), Southern region (Portugal et al. 1979, Ramos et al. 1986, Driemeier et al. 1999), Mid-western region (Brautingam et al. 1996, Acypreste et al. 2005), and Northeastern region (Mota et al. 2007) of Brazil. These reports characterize infected animals as dairy Holstein or Holstein crossbred cows, with or without history of importation.

This paper reports the first clinical and histopathological description of bovine paratuberculosis in Gyr (Bos taurus subsp. indicus) cattle, in the State of Paraíba, Brazil, and the isolation of $M$. avium subsp. paratuberculosis from fecal samples of animals from this herd.

\section{MATERIALS AND METHODS}

\section{Index case}

An 8-year-old cow from a dairy Gyr herd in the city of Umbuzeiro, State of Paraíba, Brazil, with chronic unresponsive diarrhea for over three years was submitted to clinical examination and euthanized. During necropsy, fragments of the ileum and colon were collected, frozen at $-20^{\circ} \mathrm{C}$ for bacteriology and fixed in $10 \%$ buffered formaldehyde for routine histological processing with hematoxylin-eosin (HE) and Ziehl-Neelsen staining (Prophet et al. 1994).

\section{Fecal samples for bacteria isolation}

Fecal samples from all 160 animals over 12 months of age from the herd were collected in the following year. These samples were stored at $-20^{\circ} \mathrm{C}$ and send to the Laboratório Nacional Agropecuário (Lanagro/MG, Ministério da Agricultura, Pecuária e Abastecimento [Ministry of Agriculture, Husbandry, and Food Supply]) for isolation and growth of Mycobacterium avium subsp. paratuberculosis, as described by Stabel (1997). Each sample was inoculated onto three slants of Herrold's egg-yolk agar, two of them supplemented with mycobactin J (Allied Monitor, Missouri, USA) and one unsupplemented. Samples were incubated horizontally at $37^{\circ} \mathrm{C}$ for seven days with caps loosened. Caps were then tightened and slants were oriented vertically for another incubation at $37^{\circ} \mathrm{C}$. For 6 months, slants were weekly evaluated for growth of typical $M$. avium subsp. paratuberculosis colonies. Contaminated slants were disposed of (Stabel 1997).

\section{RESULTS}

\section{Index case}

Clinically, the index case cow was severely dehydrated, cachectic, with profuse mucous diarrhea (Fig.1A). The main post-mortem findings were emaciation and thickened intestinal wall. Detailed examination of the digestive tract revealed lesions in the ileum and gross intestine. In these areas, intestinal wall was thickened, with mucosal fold protrusion on cut surface. The mucous surface, specially the ileal, had a brain-like appearance, with thickened folds resembling the circumvolutions of the cerebral hemispheres (Fig.1B).

Microscopy revealed intense infiltration of foamy macrophages distributed as nodules in the lamina propria, and diffusely in the submucosa (Fig.1C). A number of epithelioid cells and Langhans giant cells were observed in some areas of the mucosa and submucosa, associated to the macrophage infiltration. The count of intestinal crypts was reduced, both in the ileum and gross intestine. ZiehlNeelsen staining revealed a large quantity of alcohol-acid resistant bacilli in the cytoplasm of the foamy macrophages, epithelioid cells, and giant cells (Fig.1D). Mycobacterium avium subsp. paratuberculosis typically causes infiltration of large amounts of microorganisms in the cytoplasm of macrophages, unlike lesions caused by $M$. bovis and other subspecies of $M$. avium, where the amount of microorganisms detected under alcohol-acid stain is minimum (Brown et al. 2007).

The clinical, gross and histopathological findings were similar to those already described elsewhere (Whitlock \& Buergelt 1996, Driemeier et al. 1999) and made the confirmation of paratuberculosis in the index case animal possible.

Although the material sampled at necropsy of the index case cow was stored at $-20^{\circ} \mathrm{C}$, isolation of $M$. avium subsp. paratuberculosis was not possible, probably because of 
the long time, about ten months, the material were stored. Gomes et al. (2002) also reported the impossibility of isolation of $M$. avium subsp. paratuberculosis from samples of positive animals after long periods of storage.

\section{Fecal samples for bacterial isolation}

There was colony growth in two slants of Herrold's eggyolk agar supplemented with mycobactin $\mathrm{J}, 150$ days after incubation. No growth was noticed in media unsupplemented with mycobactin J. Colonies were white, opaque, shiny, humid, firm, and slightly smooth. Microscopic examination of the isolated microorganisms stained by ZiehlNeelsen revealed considerable amounts of alcohol-acid resistant bacilli, morphologically compatible with Mycobacterium spp. Based on the growth time, bacterial morphology with Ziehl-Neelsen staining, and dependence of mycobactin $\mathrm{J}$, the isolated microorganism was identified as M. avium subsp. paratuberculosis (Tiwari et al. 2006).

\section{DISCUSSION}

Before the onset of the clinical problem, this herd had remained closed for many years, without introduction of
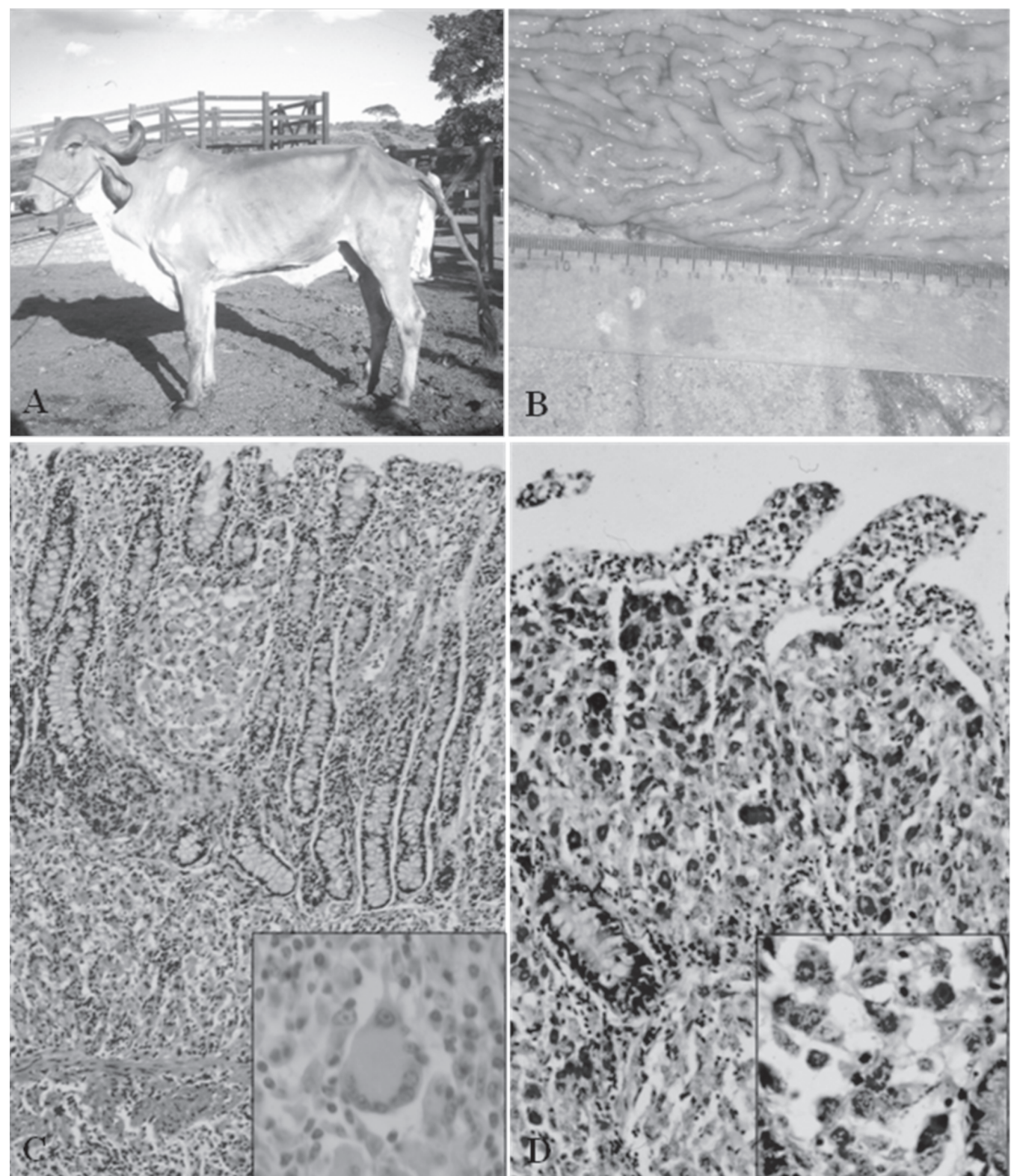

Fig.1. (A) Gyr cow (index case) showing severe dehydration and cachexia. (B) At necropsy, the ileum of the index case showed a brain-like appearance, with thickened folds resembling the circumvolutions of the cerebral hemispheres. (C) Microscopy reveals intense infiltration of foamy macrophages distributed as nodules in the lamina propria, and diffusely in the submucosa. HE staining, 50x. (C detail) Giant cells are also present. HE staining, 400x. (D) Large quantity of alcohol-acid resistant bacilli in the cytoplasm of the foamy macrophages, epithelioid cells, and giant cells is present. Ziehl-Neelsen staining, 100x. Detail 400x. 
animals or clinical manifestations that would suggest paratuberculosis. As the genetic improvement system of this dairy Gyr herd evolved, new techniques, such as embryo transfer, were adopted. Top animals were transferred in the 1990s to an embryo transfer central in the State of Minas Gerais, Brazil, where Johne's disease had already been diagnosed in Holstein cattle (Nakajima et al. 1991). The animals remained there for months, where they probably were infected. When returning to their original herd in the State of Paraíba, these animals may have been the source of dissemination of the etiological agent in the herd.

The data presented reiterate the importance of preventive sanitary control when introducing animals in herds free of paratuberculosis (Kennedy \& Benedictus 2001, McKenna et al. 2006). Moreover, these data justify the adoption of rigid biosecurity measures to avoid propagation of Mycobacterium avium subsp. paratuberculosis, because paratuberculosis is a chronic wasting disease, whose clinical manifestation is limited to a few animals, while many are asymptomatic carriers (McKenna et al. 2006), as observed in this case herein reported.

Although there are reports of paratuberculosis in almost every region of Brazil and the serious losses it causes in countries with high prevalence (Tiwari et al. 2006), little is known about paratuberculosis in Brazil, where the disease is still regarded as a subject of virtually no importance. The lack of consistent epidemiological data makes paratuberculosis be treated as a rare pathological finding in most cases (Gomes et al. 2002). Sporadic diagnoses do not allow for an accurate status evaluation (Ferreira et al. 2005). Difficulties in the in vivo diagnosis due to low sensitivity of fecal culture $(53 \%)$ and ELISA $(40 \%)$, the only available diagnostic methods, may account for the lack of reliable epidemiologic data, thus contributing to the dissemination of paratuberculosis (Whitlock et al. 2000).

All cases of paratuberculosis reported in Brazil are related to Bos taurus subsp. taurus cattle and their descendents. This is the first description of paratuberculosis in Zebu cattle (Bos taurus subsp. indicus) in the State of Paraíba, confirming that this disease is not exclusive of European breeds and is present in the Brazilian Northeastern region.

Acknowledgements.- To Dimas Assis Bandeira for the help in the collection of the samples. This project was supported by FEP-MVZ Coordenação Preventiva (Belo Horizonte, Brazil). RHML, FCFL, RCL, RMCG and APL were supported by fellowships from Conselho Nacional de Desenvolvimento Tecnológico e Científico (CNPq, Brasília, Brazil).

\section{REFERENCES}

Acypreste C.S., Juliano R.S., Rivieira F.E.B., Silva L.A.F., Fioravanti M.C.S. \& Dias Filho F.C. 2005. Uso da técnica do ELISA indireto na detecção de anticorpos anti-Mycobacterium paratuberculosis em vacas em lactação. Ciênc. Anim. Bras. 6(1):55-59.

Brautingam F.E., Glass R. \& Mendy W. 1996. Levantamento sorológico utilizando a técnica de ELISA para Paratuberculose em cinco rebanhos de corte do Mato Grosso do Sul e quatro rebanhos de leite do Estado de São Paulo. Anais XV Congresso Panamericano de Ciências Veterinárias, Campo Grande, MT, p.271.
Brown C.C., Baker D.C. \& Barker I.K. 2007. Alimentary system, p.1297. In: Maxie M.G. (Ed.), Jubb, Kennedy and Palmer's Pathology of Domestic Animals. Vol.2. $5^{\text {th }}$ ed. Saunders Elsevier, Edinburgh.

Darcoso Filho P., Campos I.O.N., Faria J.F. \& Langenegger J. 1960. Doença de Johne (paratuberculose) em bovinos nacionais. Arqs Inst. Biol. Animal, Rio de J., 3:129-139.

Driemeier D., Cruz C.E.F., Gomes M.J.P., Corbellini L.G., Loretti A.P. \& Colodel E.M. 1999. Aspectos clínicos e patológicos da paratuberculose em bovinos no Rio Grande do Sul. Pesq. Vet. Bras. 19(3/4):109115.

Dupont O. 1915. Nota do Jornal do Comércio de 5 de novembro, p.8.

Ferreira R., Fonseca L.S., Ristow P.C.L Von B. \& Lilenbaum W. 2005. Paratuberculose bovina: uma mini-revisão. Revta CFMV 36:40-53.

Fonseca L.F., Santos M.V., Pereira C.C., Olival A.A., Hienemenn M.B. \& Richtzenhain L.J. 1999. Identificação da presença de anticorpos contra Mycobacterium paratuberculosis em rebanhos leiteiros do Estado de São Paulo. Arqs Inst. Biológico, São Paulo, 66(Supl.):122.

Gomes M.J.P., Driemeier D., Ribeiro V.R., Wunder J.R., Asanome W., Lanzon A.F. \& Wald V.B. 2002. Doença de Johne: Isolamento do Mycobacterium avium subsp. paratuberculosis (MAP) em um rebanho leiteiro infectado na região sul do Brasil. Acta Scientiae Vet. 30(2):113-118.

Kennedy D.J. \& Benedictus G. 2001. Control of Mycobacterium avium subsp. paratuberculosis infection in agricultural species. Rev. Sci. Tech. 20:151-179.

McKenna S.L.B., Keefe G.P., Tiwari A., Vanleeuwen J. \& Barkema H.W. 2006. Johne's disease in Canada. Part II. Disease impacts, risk factors, and control programs for dairy producers. Can. Vet. J. 47:1089-1099.

Mota R.A., Pinheiro Junior M.J.P., Gomes M.J.P., Peixoto R.M., Maia F.C.I., Brito M.F., Chies J.A.B., Snel G.G.M. \& Juffo G.D. 2007. Paratuberculose em um rebanho bovino leiteiro no Estado de Pernambuco, PE. Arqs Inst. Biológico, São Paulo, 74(2):73-79.

Nakajima M., Maia F.C.L. \& Mota P.M.P.C. 1991. Diagnóstico da paratuberculose em Minas Gerais. Anais IV Simpósio Brasileiro de Micobactérias, Bauru, SP, 4-8 nov. (Abstract)

Portugal M.A.S.C., Pimentel J.N., Saliba A.M., Baldassi L. \& Sandoval E.F.D. 1979. Ocorrência de paratuberculose no Estado de Santa Catarina. Biológico 45(1/2):19-24.

Prophet G.B., Mills B., Arrington J.B. \& Sobin L.H. 1994. Laboratory Methods in Histotechnology. American Registry of Pathology, Armed Forces Institute of Pathology, Washington D.C., p.29-58.

Ramos E.T., Poester F.P., Correa B.L., Oliveira S.J., Rodrigues N.C. \& Canabarro C.E. 1986. Paratuberculose em bovinos do Rio Grande do Sul. Hora Vet., Porto Alegre, 6(34):28-31.

Santos J.A. \& Silva N.L. 1956. Sobre a primeira observação de paratuberculose no Brasil. Bolm Soc. Bras. Med. Vet. 24:5-11.

Silva N.M. \& Pizelli G.N. 1961. Estudos sobre paratuberculose. I. Diagnóstico de um caso da doença. Arqs Inst. Biol. Animal, Rio de J., 4:169-173.

Stabel J.R. 1997. An improved method for cultivation of Mycobacterium paratuberculosis from bovine fecal samples and comparison to three other methods. J. Vet. Diagn. Invest. 9:375-380.

Tiwari A., Vanleeuwen J.A., McKenna S.L.B., Keefe G.P. \& Barkema H.W. 2006. Johne's disease in Canada. Part I. Clinical symptoms, pathophysiology, diagnosis, and prevalence in dairy herds. Can. Vet. J. 47:874-882.

Whitlock R.H. \& Buergelt C. 1996. Preclinical and clinical manifestations of paratuberculsis (including Pathology). Vet. Clin. North Am., Food Anim. Pract. 12(2):345-356.

Whitlock R.H., Wells S.J., Sweeney R.W. \& Van Tiem J. 2000. ELISA and fecal culture for paratuberculosis (Johne's disease): Sensitivy and specificity of each method. Vet. Microbiol. 77:387-398. 